\title{
Wetsvoorstel Wet verzekerdeninvloed Zvw: één aanpassing nog dringend gewenst
}

\author{
Mr. dr. A.G.H. Klaassen*
}

\section{Inleiding}

In juni 2018 is, twee jaar nadat het Voorontwerp ${ }^{1}$ ter consultatie is aangeboden, het wetsvoorstel Wet verzekerdeninvloed Zvw (Wetsvoorstel) door minister Bruins voor Medische Zorg bij de Tweede Kamer ingediend. ${ }^{2}$ Het doel van het Wetsvoorstel is dat het belang van verzekerden meer centraal in het beleid van de zorgverzekeraar komt te staan. ${ }^{3}$ Het Wetsvoorstel stelt een inspraakregeling, waarmee individueel verzekerden invloed krijgen op het zorginkoop- en klantencommunicatiebeleid, verplicht. Met het Wetsvoorstel wordt daarnaast de grondslag gecreëerd voor een zogenoemde permanente vertegenwoordiging, deze vertegenwoordiging representeert de groep van verzekerden. Aan deze permanente vertegenwoordiging komt minimaal een instemmingsrecht ten aanzien van de inspraakregeling en een adviesrecht over het jaarlijkse zorginkoopbeleid toe. Bovendien worden aan de samenstelling van de permanente vertegenwoordiging en haar ondersteuning bepaalde eisen gesteld. Een opvallend punt is dat een aantal van deze onderwerpen in de statuten van de zorgverzekeraar dient te worden vastgelegd.

De invoering van de wet zal leiden tot aanpassing van de Zorgverzekeringswet (Zvw). De artikelen 28a, 28b, 28c, 115 en $125^{4}$ zullen aan deze wet worden toegevoegd. ${ }^{5}$ In vergelijking tot het Voorontwerp zijn de laatste twee artikelen nieuw. Verder zijn er nieuwe leden aan de artikelen $28 \mathrm{a}, 28 \mathrm{~b}$ en $28 \mathrm{c}$ toegevoegd en is op een aantal punten de tekst aangepast. ${ }^{6}$

* Ageeth Klaassen is universitair docent ondernemingsrecht aan de Erasmus Universiteit Rotterdam. Zij doceert het vak Organisatie en bestuur van de zorg in de master Recht van de gezondheidszorg; zij is lid van een raad van commissarissen in de eerstelijnsgezondheidszorg.

1 www.internetconsultatie.nl/wijziging_van_de_zvw_ivm_met_versterking_van_de_invloed_van_ verzekerden_op_de_zorgverzekeraar. Zie hierover A.G.H. Klaassen, 'Inspraak en medezeggenschap van verzekerden in de statuten van zorgverzekeraars', WPNR 2016/7130 en A.G.H. Klaassen, 'Voorontwerp Wet verzekerdeninvloed: een nieuwe vorm van medezeggenschap', TvGR 2017, p. 4-19.

2 Wijziging van de Zorgverzekeringswet in verband met versterking van de invloed van verzekerden op de zorgverzekeraar (verzekerdeninvloed Zvw), zie Kamerstukken II 2017/18, 34971, 2.

3 Kamerstukken II 2017/18, 34971, 3, p. 2.

4 Hiervoor wordt het huidige art. $125 \mathrm{Zvw}$ overschreven. De nieuwe evaluatiebepaling voorziet in een evaluatie van voorliggende wijzigingen binnen drie jaar na de inwerkingtreding ervan, zie Kamerstukken II 2017/18, 34971, 3, p. 2.

5 Ook zal de Wet marktordening gezondheidszorg worden gewijzigd. Met art. III en IV wordt art. 28a Zvw uit het (initiatief)Voorstel van wet van de leden Leijten, Bruins Slot en Nijboer houdende een verbod op winstuitkering door zorgverzekeraars vernummerd tot art. $28 \mathrm{~d} \mathrm{Zvw}$, indien dit Voorstel tot wet wordt verheven en in werking is getreden voordat deze wet in werking treedt. Zie Kamerstukken I 2016/17, 34522, A. Zie ook Kamerstukken II 2017/18, 34995, 2.

6 Tegelijkertijd zijn de adviezen van Actal en de Commissie Vennootschapsrecht en de Uitvoerings- en handhavingstoets van de NZa gepubliceerd. 
De vraag van deze bijdrage is dan ook: is het Wetsvoorstel een verbetering ten opzichte van het Voorontwerp? Zo niet, wat dient er nog te worden aangepast?

De opzet van deze bijdrage is als volgt. Ik ga eerst in op de achtergrond van het Wetsvoorstel (paragraaf 2). Daarna ga ik in paragraaf 3 in op de hoofdlijnen van het Wetsvoorstel. De inspraakregeling is onderwerp van paragraaf 4. Paragraaf 5 gaat over de permanente vertegenwoordiging. In paragraaf 6 en 7 worden respectievelijk het instemmingsrecht en het adviesrecht (van de permanente vertegenwoordiging) besproken. Het toezicht en de handhaving staan centraal in paragraaf 8. In paragraaf 9 wordt ingegaan op de rol van de statuten in het Wetsvoorstel. Paragraaf 10 bevat de conclusie en de aanbevelingen.

\section{Achtergrond}

De aanleiding van het Wetsvoorstel is gelegen in het rapport 'De stem van de verzekerden' van de Raad voor de Volksgezondheid (RVZ nu: RVS ${ }^{7}$. In dit rapport zijn voorstellen gedaan om de positie van de verzekerden in het zorginkoopproces te verankeren. ${ }^{8}$ Daarna hebben verscheidene Kamerleden in verschillende moties opgeroepen om de invloed van verzekerden op het beleid van zorgverzekeraars te versterken ten behoeve van het evenwicht in het zorgstelsel. ${ }^{9}$ In 2015 kondigde minister Schippers van Volksgezondheid, Welzijn en Sport (VWS) aan dat de invloed van verzekerden op zorgverzekeraars met een algemene maatregel van bestuur $(\mathrm{AMvB})^{10}$ moest worden vergroot. ${ }^{11}$ Door een debat met de Tweede Kamer werd duidelijk dat een $\mathrm{AMvB}$ niet voldoende werd geacht. ${ }^{12}$ Op verzoek van de minister van VWS hebben het Instituut Beleid \& Management Gezondheidszorg (IBMG nu: ESHPM ${ }^{13}$ ) en De Nederlandsche Bank (DNB) geadviseerd over hoe de invloed van verzekerden kan worden vormgegeven. ${ }^{14}$ Dit heeft in 2016 geresulteerd in het Voorontwerp. Met het Regeerakkoord 'Vertrouwen in de toekomst' uit 2017 werd nogmaals duidelijk dat de inspraak van verzekerden wettelijk zou worden vastgelegd. ${ }^{15}$ In 2018 is, zoals gezegd, het Wetsvoorstel bij de Tweede Kamer ingediend.

Momenteel is in artikel 28 lid 1 onderdeel b Zvw geregeld dat de statuten van een zorgverzekeraar waarborgen bieden voor een redelijke mate van invloed van verzekerden op het beleid. De Zvw laat de zorgverzekeraars hierbij een grote mate van vrijheid. In de praktijk blijken verzekerden via diverse instrumenten invloed te hebben op het beleid van hun zorgverzekeraar. Aangezien de positie van verzekerden per zorgverzekeraar kan verschillen, wordt het noodzakelijk geacht een wettelijk kader te scheppen met daarin minimum-

7 Raad voor Volksgezondheid en Samenleving.

8 RVZ, 'De stem van de verzekerden', Den Haag 2014.

9 Kamerstukken II 2013/14, 33362, 35 (motie Slob c.s.) en Kamerstukken II 2013/14, 33362, N (motie Kuiper c.s.) en Bouwmeester/Dik-Faber (Kamerstukken II 2015/16, 34300 XVI, nr. 94 (ter vervanging van nr. 52)).

10 Zie art. 28 lid 2 Zvw.

11 Kamerstukken II 2014/15, 31765, 116.

12 Handelingen II 2014/15 53, item 8, p. 1-32.

13 Erasmus School of Health Policy \& Management.

14 Zie H. van de Bovenkamp, P. Meurs \& M. de Lint, 'Gevarieerde medezeggenschap in zorginstellingen en bij zorgverzekeraars', Instituut Beleid \& Management Gezondheidszorg (IBMG), Erasmus Universiteit Rotterdam mei 2016, p. 31 en Bijlage bij Kamerstukken II 2015/16, 31765, 209.

Kamerstukken II 2017/18, 34700, 34. 
eisen voor verzekerdeninvloed. ${ }^{16}$ Het belang van de nieuwe wet is dat bij iedere zorgverzekeraar de verzekerdeninvloed na inwerkingtreding van de wet in elk geval dient te voldoen aan de in de wet gestelde eisen. ${ }^{17}$ De vraag blijft wel of verzekerden daadwerkelijk gebruik gaan maken van de mogelijkheden tot uitoefening van invloed en de wijze waarop. ${ }^{18}$ Formeel kan de medezeggenschap goed geregeld zijn, de praktijk zal - net zoals bij de uitoefening van medezeggenschap door cliënten bij zorginstellingen - ongetwijfeld weerbarstiger blijken te zijn. ${ }^{19}$

\section{Hoofdlijnen van het Wetsvoorstel}

Met het Wetsvoorstel wordt de invloed van verzekerden op twee manieren versterkt. ${ }^{20}$ Ten eerste worden zorgverzekeraars verplicht om individuele verzekerden gelegenheid te bieden om hun meningen en wensen kenbaar te maken ten aanzien van de door zorgverzekeraar en (permanente) vertegenwoordiging afgesproken onderdelen van het beleid, waaronder in elk geval het zorginkoopbeleid en het klantcommunicatiebeleid als meest relevante beleidsterreinen. Dit dient te worden vastgelegd in de zogenoemde inspraakregeling (zie paragraaf 4).

Ten tweede worden zorgverzekeraars verplicht om een adviserende permanente verzekerdenvertegenwoordiging te borgen, die bovendien als 'hoedster' van verzekerdeninspraak fungeert. De permanente vertegenwoordiging krijgt een adviesrecht over het jaarlijkse zorginkoopbeleid (zie paragraaf 7) en een instemmingsrecht ten aanzien van de hiervoor genoemde inspraakregeling (zie paragraaf 6). Bovendien worden eisen gesteld aan de samenstelling en ondersteuning van de permanente vertegenwoordiging (zie paragraaf 5).

Bij de vormgeving van deze 'invloed van verzekerden' geldt dat de voorgestelde wettelijke eisen zodanig zijn dat zij voldoende concreet zijn om de invloed van verzekerden op het beleid van de zorgverzekeraar te verbeteren, maar ook dient voldoende ruimte te worden gelaten voor zorgverzekeraars en verzekerden om invulling aan de eisen te geven binnen de huidige diversiteit van rechtsvormen van de zorgverzekeraars, ${ }^{21}$ de inrichting van de concerns waartoe zij behoren ${ }^{22}$ en de wijze waarop de vertegenwoordiging van verzekerden momenteel is geregeld. ${ }^{23}$

16 Kamerstukken II 2017/18, 34971, 3, p. 2.

17 Kamerstukken II 2017/18, 34971, 3, p. 2.

18 In de MvT staat dat de behoefte aan het vergroten van de directe participatie van (individuele) verzekerden onder betrokkenen breed wordt gevoeld, zie Kamerstukken II 2017/18, 34971, 3, p. 13.

19 Zie IBMG 2016 (zie noot 14), p. 16 e.v.

20 Zie voor de verhouding van het Wetsvoorstel met art. 206 van Richtlijn 2009/138/EG (Solvabiliteit II), Kamerstukken II 2017/18, 34971, 3, p. 3.

21 Op grond van art. 3:20 Wft dient een zorgverzekeraar die zijn zetel in Nederland heeft de rechtsvorm nv, onderlinge waarborgmaatschappij (OWM) of Europese vennootschap te hebben.

22 In Nederland zijn er zorgverzekeraars (concerns) met verschillende labels (merken). De moedermaatschappij kan, naast een OWM of nv, ook een coöperatie of bv zijn. In het laatste geval, van de bv's, is een vereniging de (grootste) aandeelhouder.

23 Dit heeft tot gevolg dat binnen de verzekeringsconcerns, met uitzondering van ASR (de enige nv), zeggenschap van verzekerden plaatsvindt in een ledenraad. 


\section{Inspraakregeling}

Op grond van artikel 28a lid 1 Zvw (nieuw) dient een zorgverzekeraar een schriftelijke regeling vast te stellen waarin wordt bepaald op welke onderdelen van het beleid hij zijn verzekerden in de gelegenheid stelt inspraak uit te oefenen. Onder inspraak wordt verstaan: meningen en wensen kenbaar kunnen maken, zo wordt in de memorie van toelichting (MvT) uitgelegd. ${ }^{24}$ In de schriftelijke regeling wordt ook vastgelegd op welke wijze de inspraak kan worden verkregen en op welke wijze de verzekerden worden geïnformeerd over de resultaten van de inspraak alsmede over wat daarmee is gedaan.

In lid 3 van artikel 28a Zvw (nieuw) staat dat de zorgverzekeraar zijn verzekerden in de gelegenheid stelt inspraak uit te oefenen conform deze vastgestelde (schriftelijke) inspraakregeling. Dit betekent dat de zorgverzekeraar niet alleen verplicht is om de gelegenheid tot inspraak te bieden op de in de regeling aangewezen onderdelen van het beleid, maar dat hij dit ook moet doen op de in de regeling bepaalde wijze, terwijl hij bovendien aan de in de regeling opgenomen bepalingen over de terugkoppeling moet voldoen, zo staat in de MvT. ${ }^{25}$ De tekst van zowel lid 1 (voorheen lid 2) als lid 3 (voorheen lid 1) stond ook in het Voorontwerp. De MvT verschaft over deze wijziging van de volgorde van de leden verder geen informatie. Aan de schriftelijke inspraakregeling worden een aantal (concrete) eisen gesteld.

\section{Onderwerpen}

In de schriftelijke regeling dient op grond van artikel 28a lid 2 Zvw (nieuw) in elk geval te worden vastgelegd over welke onderdelen van het zorginkoopbeleid (onderdeel a luidt: 'het met zorgaanbieders sluiten van overeenkomsten met betrekking tot de zorg of overige diensten') en het klantencommunicatiebeleid (onderdeel b luidt: 'de wijze waarop de zorgverzekeraar met zijn verzekerden communiceert') de verzekerden inspraak hebben. Het is een bewuste keuze om verplichte inspraak over deze twee beleidsterreinen te geven. ${ }^{26}$ Onder het begrip zorginkoopbeleid vallen alle afspraken die zorgverzekeraars (of hun concerns) ${ }^{27}$ met (zorg)aanbieders maken ter zake van de door hen aan hun verzekerden te leveren zorg of andere op grond van de zorgverzekering verzekerde diensten, zo staat in de MvT. ${ }^{28}$ Onder klantcommunicatiebeleid wordt volgens de MvT verstaan de wijze waarop

Kamerstukken II 2017/18, 34971, 3, p. 8.

Kamerstukken II 2017/18, 34971, 3, p. 30.

Kamerstukken II 2017/18, 34971, 3, p. 8.

Zie over de verhouding individuele zorgverzekeraar en het concern waarvan hij deel uitmaakt, Kamerstukken II $2017 / 18,34971,3$, p. 8.

Kamerstukken II 2017/18, 34971, 3, p. 8. Hierbij kan worden gedacht aan de contracten die zorgverzekeraars voor in natura verzekerde zorg met zorgaanbieders sluiten, maar ook voor zorg die op restitutiebasis verzekerd is kunnen zorgverzekeraars contracten met aanbieders sluiten. Het ligt meer voor de hand dat inspraak wordt gegeven op - bijvoorbeeld - de diversiteit van de te contracteren zorg en de regionale organisatie ervan dan - bijvoorbeeld - op de af te spreken tarieven voor de zorg. 
de zorgverzekeraar met zijn verzekerden communiceert. ${ }^{29}$ In het Voorontwerp werd nog gesproken over 'hoofdlijnen van het zorginkoopbeleid'. Aangezien in het Wetsvoorstel nader wordt omschreven om welke aspecten van het beleid het gaat, en de MvT deze (wettelijke) omschrijvingen nog nader invult, is er vermoedelijk voldoende duidelijkheid waarover minimaal inspraak moet worden vastgesteld.

Bovendien kan in de inspraakregeling verder worden bepaald voor welke andere beleidsonderdelen verzekerden in de gelegenheid worden gesteld om hun meningen en wensen kenbaar te maken. Voor de hand ligt bijvoorbeeld inspraak in het polisaanbod en het marketingbeleid. ${ }^{30}$ Deze andere beleidsonderwerpen blijven facultatief omdat het regelen van inspraak zo veel mogelijk overgelaten moet worden aan de zorgverzekeraar en de permanente vertegenwoordiging, aldus de MvT. ${ }^{31}$

\section{Transparantie}

De zorgverzekeraar maakt de inspraakregeling openbaar, zo staat in artikel 28a lid 5 Zvw (nieuw). In het Voorontwerp stond dat de regeling alleen bekend moest worden gemaakt aan verzekerden. Op basis van de tekst in het Wetsvoorstel kan eenieder de inspraakregeling raadplegen. ${ }^{32}$ Dit is een verbetering, omdat met deze tekstwijziging duidelijk wordt dat transparantie zowel van belang is voor verzekerden als voor aspirant-verzekerden. De website van de zorgverzekeraar is het meest voor de hand liggend. Indien de (aspirant-)verzekerde een verzoek doet tot het verkrijgen van de tekst van de inspraakregeling, ligt het daarnaast voor de hand dat de zorgverzekeraar deze e-mailt of deze per post opstuurt, aldus de MvT. ${ }^{33}$

\section{Permanente vertegenwoordiging}

Met de nieuwe bepalingen in de Zvw wordt de grondslag gecreëerd voor de zogenoemde permanente vertegenwoordiging. Wat wordt verstaan onder de permanente vertegenwoordiging? De wet en de MvT geven van het begrip geen definitie. Uit de MvT wordt wel duidelijk dat, zoals de naam al zegt, de vertegenwoordiging permanent is. Hierdoor onderscheidt een permanente vertegenwoordiging zich van min of meer incidentele vormen van vertegenwoordiging van verzekerden, zoals een klantenpanel. ${ }^{34}$ Volgens de MvT kan een permanente vertegenwoordiging bestaan uit een bestaande ledenraad, verzekerdenraad of

29 Kamerstukken II 2017/18, 34971, 3, p. 8. Bij inspraak in dit beleid valt te denken aan het voorleggen van een voorgenomen klantenbericht aan verzekerden die het kunnen toetsen op begrijpelijkheid. Of het nagaan bij verzekerden op welke wijze (bijvoorbeeld per post, e-mail, telefoon, app, 'mijn-omgeving') zij graag informatie van de zorgverzekeraar willen ontvangen of met de zorgverzekeraar willen communiceren. Ook de frequentie waarop de zorgverzekeraar over bepaalde onderwerpen met de verzekerden communiceert en de tijdstippen waarop dit gebeurt, kunnen onder de wijze van communiceren worden verstaan.

30 Kamerstukken II 2017/18, 34971, 3, p. 9.

31 Kamerstukken II 2017/18, 34971, 3, p. 15.

32 Kamerstukken II 2017/18, 34971, 3, p. 15 (en p. 10).

33 Kamerstukken II 2017/18, 34971, 3, p. 10.

34 Kamerstukken II 2017/18, 34971, 3, p. 28. 
een andere daartoe ingestelde vertegenwoordiging. ${ }^{35}$ Dit kan op het niveau van de zorgverzekeraar, maar in beginsel volstaat ook een vertegenwoordiging op concernniveau. ${ }^{36}$

\subsection{Samenstelling}

Artikel 28b Zvw (nieuw) stelt eisen aan de samenstelling van de permanente vertegenwoordiging Dit zijn meer eisen dan het Voorontwerp aan de samenstelling stelde. Hetgeen in lid 2 en lid 3 staat is onder andere (grotendeels) toegevoegd.

\section{- Leden}

Het aantal leden van de permanente vertegenwoordiging dient in de statuten ${ }^{37}$ te worden vastgelegd, aldus artikel 28b lid $3 \mathrm{Zvw}$ (nieuw). Deze eis is nieuw. Deze eis uit de Zvw geldt met name voor verzekerdenraden of een daartoe ingestelde vertegenwoordiging. Voor de ledenraad is deze eis al in Boek 2 BW vastgelegd. ${ }^{38}$ Deze eis is ook voor een verzekerdenraad of een daartoe ingestelde vertegenwoordiging gewenst, omdat het niet zo kan zijn dat het aantal door de tijd heen zodanig fluctueert dat niemand weet hoeveel leden er zijn of zouden moeten zijn. Indien het aantal (feitelijke) leden onder het vastgelegde aantal komt, dient actief te worden gezocht naar een nieuw lid. Dit geldt temeer door de rechten die in de nieuwe bepalingen in de Zvw aan de permanente vertegenwoordiging worden toegekend.

De eis uit het Voorontwerp van 'representatieve (permanente) vertegenwoordigers' is vervallen. Deze eis kon vervallen, omdat het Wetsvoorstel de representativiteit nader concretiseert in onderdelen a $\mathrm{t} / \mathrm{m} \mathrm{c}$. Uit de consultatie is gebleken dat het onwenselijk werd gevonden dat dit niet nader was omschreven. ${ }^{39}$

Ten eerste bepaalt artikel 28b lid $1 \mathrm{Zvw}$ (nieuw) dat de permanente vertegenwoordiging uitsluitend uit verzekerden van de zorgverzekeraar kan bestaan. In het geval de zorgverzekeraar deel uitmaakt van een concern dient de permanente vertegenwoordiging te bestaan uit vertegenwoordigers van de verzekerden van alle betrokken zorgverzekeraars van het concern.

Ten tweede dient volgens artikel 28b lid 2 onderdeel a Zvw (nieuw) de permanente vertegenwoordiging, voor zover mogelijk, zodanig samengesteld te zijn dat de vertegenwoordiging wat betreft leeftijd en opleiding een goede afspiegeling is van de verzekerden. ${ }^{40}$ Onderdeel b verlangt dat de samenstelling, voor zover mogelijk, zodanig is dat de vertegenwoordiging redelijkerwijs de diverse belangen van de verzekerden kan behartigen. Hierbij gaat het erom dat de vertegenwoordiger vanuit een voldoende maatschappelijk besef en vanuit eigen kennis en ervaring zijn rol kan vervullen. ${ }^{41}$ In het geval de zorgverzekeraar deel uitmaakt van een concern dienen volgens onderdeel c de permanente vertegenwoordigers, voor zover mogelijk, evenwichtig te zijn verdeeld over de betrokken zorgver-

Kamerstukken II 2017/18, 34971, 3, p. 10 en p. 28.

Er zal dan sprake moeten zijn van een vertegenwoordiging waarin de verzekerden van alle betrokken zorgverzekeraars worden vertegenwoordigd. Kamerstukken II 2017/18, 34971, 3, p. 11 en p. 22.

Zie par. 9, mijns inziens is een schriftelijke regeling voldoende.

Art. 2:39 lid $1 \mathrm{BW}$.

Kamerstukken II 2017/18, 34971, 3, p. 15.

In de statuten kan de betrokken rechtspersoon nog aanvullende eisen ter zake stellen, zie Kamerstukken II $2017 / 18,34971,3$, p. 32.

41 Kamerstukken II 2017/18, 34971, 3, p. 32. 
zekeraars. Overigens kan een groot verschil in omvang van de verschillende zorgverzekeraars met zich meebrengen dat er enig verschil is in aantallen vertegenwoordigers. ${ }^{42}$ Deze eisen dienen in de statuten te worden vastgelegd. ${ }^{43}$ Het gaat om een (maximale) inspanningsverplichting. ${ }^{44}$ Met de genoemde (wettelijke) criteria wordt richting gegeven waar bij de samenstelling van de permanente vertegenwoordiging op gelet dient te worden. In de praktijk zal het niet altijd mogelijk zijn te voldoen aan deze onderdelen, vandaar de toevoeging van de woorden 'voor zover mogelijk'. Zoals terecht in de MvT wordt opgemerkt: 'de uiteindelijke samenstelling zal immers vaak afhankelijk zijn van de animo en bereidheid van verzekerden om zitting te nemen in een permanente vertegenwoordiging'. ${ }^{45}$

\section{- Wijze van benoeming}

In tegenstelling tot het Voorontwerp bevat het Wetsvoorstel een bepaling over de wijze waarop de leden van de permanente vertegenwoordiging (kunnen) worden benoemd. Artikel 28b lid $3 \mathrm{Zvw}$ (nieuw) eist dat dit in de statuten ${ }^{46}$ wordt vastgelegd. Deze eis is opgenomen voor het geval dat een verzekerdenraad of een daartoe ingestelde vertegenwoordiging wordt aangewezen als permanente vertegenwoordiging. Voor de ledenraad eist Boek 2 BW al dat de wijze van benoeming (in de statuten) wordt vastgelegd. ${ }^{47}$ De zorgverzekeraar heeft hierbij dus vrijheid hoe de benoeming wordt vormgegeven. Hierbij geldt wel dat elke verzekerde van 18 jaar of ouder in de gelegenheid dient te worden gesteld zich kandidaat te stellen, zo staat in lid $3 .{ }^{48}$

\subsection{Ondersteuning}

De bepalingen over de ondersteuning aan de permanente vertegenwoordiging zijn ten opzichte van het Voorontwerp slechts tekstueel gewijzigd. Er wordt niet meer gesproken over de 'taak', maar over de 'werkzaamheden' van de permanente vertegenwoordiging. Met het begrip 'werkzaamheden' wordt gedoeld op de werkzaamheden die de (permanente) vertegenwoordiging verricht in het kader van de Zvw. ${ }^{49}$ Indien een ledenraad wordt aangewezen als permanente vertegenwoordiging, wordt hiermee onderscheid gemaakt tussen de taken op grond van Boek 2 BW en de werkzaamheden op grond van de Zvw. De ondersteuning is alleen bedoeld voor de Zvw-werkzaamheden. ${ }^{50}$

\section{- Openbare vacature}

De zorgverzekeraar draagt er volgens artikel 28b lid 4 onderdeel a Zvw (nieuw) zorg voor dat de vacature voor de permanente vertegenwoordiging openbaar wordt gemaakt. Dit stond op een kleine tekstuele wijziging na ook al in het Voorontwerp. ${ }^{51}$ Dit is een voorwaarde om de onafhankelijkheid van de leden van de permanente vertegenwoordiging te

42 Kamerstukken II 2017/18, 34971, 3, p. 33.

43 Zie par. 9, mijns inziens is een schriftelijke regeling voldoende.

44 Kamerstukken II 2017/18, 34971, 3, p. 15.

45 Kamerstukken II 2017/18, 34971, 3, p. 20.

46 Zie par. 9, mijns inziens is een schriftelijke regeling voldoende.

47 Art. 2:39 lid 1 BW.

48 Zie ook par. 5.2.

49 Kamerstukken II 2017/18, 34971, 3, p. 34.

50 Kamerstukken II 2017/18, 34971, 3, p. 34.

51 In het Voorontwerp stond 'vacature van de vertegenwoordiging'. 
borgen, aldus de MvT. Bij de vacature dient ook een profielschets te worden gevoegd, waarin de gezochte kwaliteiten van het nieuwe lid en de aan het lid gestelde eisen worden genoemd. ${ }^{52}$

\section{- Voorzieningen}

Artikel 28b lid 4 onderdeel b Zvw (nieuw) bepaalt dat de zorgverzekeraar ervoor zorgdraagt dat de vertegenwoordiging gebruik kan maken van de voorzieningen die zij redelijkerwijs nodig heeft voor de vervulling van haar werkzaamheden. Dit stond ook in het Voorontwerp. In de MvT wordt verduidelijkt dat onder voorzieningen het gebruik van kopieerapparaten, vergaderfaciliteiten en computers vallen. ${ }^{53}$ Deze opsomming is uitgebreider dan die in de toelichting bij het Voorontwerp.

\section{- Kosten}

In artikel $28 \mathrm{~b}$ lid 4 onderdeel c Zvw (nieuw) wordt bepaald dat de zorgverzekeraar ervoor zorgdraagt dat wordt voorzien in de kosten die redelijkerwijs noodzakelijk zijn voor de vervulling van de werkzaamheden van de vertegenwoordiging, waaronder de kosten die verband houden met scholing, onafhankelijke ondersteuning en het voeren van rechtsgedingen. Aan dit onderdeel is het woord 'redelijkerwijs' toegevoegd, om dit onderdeel niet onnodig van het wetsvoorstel Wet medezeggenschap cliëntenrechten zorg (Wmcz) $2018^{54}$ te laten afwijken. ${ }^{55}$ Aangezien rechtsgedingen ook bij de kantonrechter kunnen worden gevoerd, is het deel dat het alleen ging om verzoeken bij de Nederlandse Zorgautoriteit (NZa) terecht geschrapt. Uit het Voorontwerp bleek niet duidelijk of de kosten voor het inhuren van een deskundige voor rekening kwamen van de zorgverzekeraar. ${ }^{56}$ Uit de MvT blijkt dat indien een dergelijk (extern) advies noodzakelijk is voor de uitvoering van de taak van de vertegenwoordiging, de zorgverzekeraar moet voorzien in de bekostiging daarvan. ${ }^{57}$ Dit is een gewenste verduidelijking.

\section{- Informatie}

Op grond van artikel 28b lid $5 \mathrm{Zvw}$ (nieuw) verstrekt de zorgverzekeraar de permanente vertegenwoordiging tijdig en desgevraagd schriftelijk alle inlichtingen en gegevens die zij voor de vervulling van haar werkzaamheden redelijkerwijs nodig heeft. Dit stond ook in het Voorontwerp, maar in een ander lid, namelijk lid 3. Deze wijziging van het lidnummer komt door de toevoeging van twee nieuwe leden aan artikel 28b Zvw (nieuw).

\section{- Verantwoording}

Lid 6 bepaalt dat de zorgverzekeraar de vertegenwoordiging desgevraagd hulp verleent bij a. het inventariseren van de wensen en meningen van de betrokken verzekerden, en $b$. het

52 Kamerstukken II 2017/18, 34971, 3, p. 16 en p. 33.

53 Kamerstukken II 2017/18, 34971, 3, p. 34.

54 Nieuwe bepalingen met betrekking tot de medezeggenschap van cliënten in zorginstellingen (Wet medezeggenschap cliënten zorginstellingen 2018), zie Kamerstukken II 2017/18, 34858, 2.

55 Kamerstukken II 2017/18, 34971, 4, p. 7. Zie art. 6 lid 3 Wmcz 2018 (nieuw). In mijn ogen komt in deze bepaling duidelijker tot uitdrukking dat de kosten daadwerkelijk betaald moeten worden.

56 Zie ook Klaassen TvGR 2017, p. 13. Vgl. art. 16 WOR.

57 Kamerstukken II 2017/18, 34971, 3, p. 17. 
informeren van de betrokken verzekerden over de werkzaamheden van de vertegenwoordiging en de resultaten daarvan. In het Voorontwerp stond (alleen) dat de zorgverzekeraar de vertegenwoordiging stimuleert de verzekerden bij de zorgverzekeraar over haar werkzaamheden te informeren en te raadplegen. Deze tekst is gewijzigd om dit Wetsvoorstel niet onnodig te laten afwijken van het wetsvoorstel Wmcz $2018 .{ }^{58}$ De nieuwe tekst is in mijn ogen een verbetering omdat de permanente vertegenwoordiging hiertoe niet gestimuleerd zou hoeven te worden, dit vloeit voort uit haar werkzaamheden. Zij moet deze werkzaamheden alleen wel kunnen vervullen. Deze laatste verantwoordelijkheid berust bij de zorgverzekeraar en dat blijkt uit lid $6 .^{59}$

\section{Instemmingsrecht}

Artikel 28a lid 4 Zvw (nieuw) bepaalt dat de zorgverzekeraar de instemming behoeft van de permanente vertegenwoordiging voor de vaststelling, wijziging of intrekking van de inspraakregeling.

De invloed van de vertegenwoordiging gaat hierbij volgens de MvT niet zo ver dat sprake is van een vetorecht. ${ }^{60}$ Indien de beslissing van de permanente vertegenwoordiging om de instemming aan de inspraakregeling te onthouden onredelijk is, kan de zorgverzekeraar de inspraakregeling vaststellen zonder instemming van de vertegenwoordiging, zie de tweede zin van lid $4 .{ }^{61}$ Hetzelfde geldt voor de situatie waarin de zorgverzekeraar de instemming van de vertegenwoordiging heeft gevraagd, maar een beslissing van de vertegenwoordiging uitblijft of deze vertegenwoordiging het nemen van een beslissing blijft uitstellen. ${ }^{62}$ Wel is het de bedoeling dat de zorgverzekeraar en de permanente vertegenwoordiging in overleg gaan om tot overeenstemming te komen. ${ }^{63}$

Deze tweede zin is een aanvulling ten opzichte van het Voorontwerp. ${ }^{64}$ De kantonrechter kan (na eventuele tussenkomst van de raad van commissarissen ${ }^{65}$ beoordelen of de permanente vertegenwoordiging zich onredelijk opstelt (of dat de inspraakregeling ten onrechte zonder instemming is vastgesteld). ${ }^{66}$ De toevoeging van de tweede zin is een goede zaak. De inspraakregeling is een dusdanige belangrijke pijler voor de versterking van invloed van verzekerden dat voorzien moet zijn in een maatregel die de totstandkoming (of aanpassing) van een dergelijk regeling bevordert.

58 Kamerstukken II 2017/18, 34971, 4, p. 7. Zie art. 5 lid 2 Wmcz 2018 (nieuw).

59 Zie ook Klaassen TvGR 2017, p. 14.

60 Kamerstukken II 2017/18, 34971, 3, p. 11. Hiermee blijft de beslissingsbevoegdheid bij het bestuur, dat tevens eindverantwoordelijk is voor de beslissingen die worden genomen.

61 Voorbeelden van situaties die in de MvT worden genoemd zijn: dat, ondanks rappel door de zorgverzekeraar, de permanente vertegenwoordiging niet binnen een redelijke termijn een beslissing neemt, of wanneer de vertegenwoordiging zodanige eisen aan de regeling stelt dat die regeling ertoe zou leiden dat de zorgverzekeraar niet goed meer bestuurd zou kunnen worden.

62 Kamerstukken II 2017/18, 34971, 3, p. 11.

63 Kamerstukken II 2017/18, 34971, 3, p. 31.

64 Vermoedelijk om te voorkomen dat bij een weigering om instemming te geven het besluit van het bestuur van de zorgverzekeraar tot het vaststellen van de inspraakregeling nietig zou zijn, zie Kamerstukken II 2017/18, 34971, 3, p. 21. Zie ook par. 9.

65 Zie verder par. 8.1.

66 Zie ook par. 8.3. 


\section{Adviesrecht}

Jaarlijks zorginkoopbeleid

Op grond van artikel 28c lid 1 Zvw (nieuw) stelt de zorgverzekeraar de permanente vertegenwoordiging in de gelegenheid advies uit te brengen over de vaststelling, wijziging of intrekking van het jaarlijkse zorginkoopbeleid. Er is bewust voor deze formulering gekozen, omdat het niet de bedoeling is dat het adviesrecht zich uitstrekt over alle technische zaken en details van zorginkoop, het gaat om het beleid van zorginkoop. ${ }^{67}$ In het Voorontwerp stond dat het adviesrecht in ieder geval betrekking had op het jaarlijkse zorginkoopbeleid. De woorden 'in ieder geval' zijn niet meer nodig door de toevoeging van lid 6, waaruit blijkt dat het adviesrecht kan worden uitgebreid (zie hierna).

\section{Procedure}

Het advies wordt volgens artikel 28c lid 2 Zvw (nieuw) op een zodanig tijdstip gevraagd, dat de permanente vertegenwoordiging redelijkerwijs genoeg tijd heeft zich een goed oordeel ter zake te vormen en dat het advies van wezenlijke invloed kan zijn op het jaarlijkse zorginkoopbeleid. De woorden 'de vertegenwoordiging redelijkerwijs genoeg tijd heeft zich een goed oordeel ter zake te vormen' zijn nieuw ten opzichte van het Voorontwerp. In de MvT staat dat de lengte van deze periode onder meer kan afhangen van de wijze waarop de zorgverzekeraar de stukken aan de vertegenwoordiging aanbiedt. ${ }^{68}$ Deze toevoeging is waardevol in het kader van de bewustwording dat de zorgverzekeraar serieus rekening moet houden met het tijdig vragen van advies en dat niet zonder goede voorbereiding een standpunt van de permanente vertegenwoordiging kan worden verwacht. Zij hebben 'recht' op een zorgvuldig proces van voorbereiding en besluitvorming om tot een advies te komen.

De permanente vertegenwoordiging brengt op grond van artikel 28c lid 3 Zvw (nieuw) schriftelijk advies uit en betrekt daarin hetgeen is gedaan met de resultaten van de inspraak als bedoeld in artikel 28a lid 2 onderdeel a Zvw (zorginkoopbeleid). In tegenstelling tot het Voorontwerp hoeft bij het advies de uitvoering van de inspraakregeling niet meer te worden betrokken. Indien de uitspraakregeling niet goed wordt uitgevoerd, staat onder het Wetsvoorstel de weg naar de kantonrechter open.

De zorgverzekeraar doet van de vaststelling, wijziging of intrekking van het jaarlijkse zorginkoopbeleid schriftelijk, en voor zover van het advies wordt afgeweken onder opgave van redenen, mededeling aan de vertegenwoordiging, zo staat in artikel 28c lid $5 \mathrm{Zvw}$ (nieuw). Dit stond ook al in het Voorontwerp. De Zvw stelt een overleg tussen de zorgverzekeraar

68 Kamerstukken II 2017/18, 34971, 3, p. 35. Indien de zorgverzekeraar bijvoorbeeld een goede annotatie meestuurt, waarin op heldere en toegankelijke wijze de beweegredenen voor de verschillende keuzes zijn opgenomen, alsmede de gevolgen die het voorgenomen inkoopbeleid naar verwachting zal hebben voor de verschillende groepen van verzekerden, kan redelijkerwijs met een kortere periode worden volstaan dan in gevallen waarin uitsluitend het document van het jaarlijkse zorginkoopbeleid aan de vertegenwoordiging wordt toegestuurd. Zie voor een punt van aandacht Kamerstukken II 2017/18, 34971, 3, p. 16 (eerste alinea). 
en de permanente vertegenwoordiging niet verplicht, ${ }^{69}$ maar wanneer een advies van de permanente vertegenwoordiging door de zorgverzekeraar niet serieus wordt genomen, kan de vertegenwoordiging naar de kantonrechter stappen. ${ }^{70} \mathrm{Ik}$ raad aan om toch eerst te overleggen voor dat een procedure met de nodige kosten wordt gestart en de verhoudingen op scherp worden gezet.

\section{Ongevraagd advies}

Artikel 28c lid $4 \mathrm{Zvw}$ (nieuw) bepaalt dat de permanente vertegenwoordiging bevoegd is de zorgverzekeraar ongevraagd te adviseren over het jaarlijkse zorginkoopbeleid. Dit lid stond niet in het Voorontwerp. De MvT noemt als voorbeeld dat de vertegenwoordiging hieraan behoefte kan hebben als er bepaalde aspecten van het jaarlijkse zorginkoopbeleid zijn die de vertegenwoordiging alvast in een zeer vroeg stadium aan de zorgverzekeraar mee wil geven. ${ }^{71}$ Dit (nieuwe) lid is een verbetering ten opzichte van het Voorontwerp, omdat deze mogelijkheid beter uit de wet zelf kan blijken dan uit de toelichting op de wet. $^{72}$

\section{Uitbreiding adviesrecht}

In artikel 28c lid 6 Zvw (nieuw) staat dat indien de zorgverzekeraar in zijn statuten ${ }^{73}$ bepaalt dat de permanente vertegenwoordiging ook over andere onderdelen van het beleid advies uit kan brengen, het bepaalde in het eerste tot en met vijfde lid van overeenkomstige toepassing is. Dit lid stond nog niet in het Voorontwerp. De procedure is dan hetzelfde als bij advies op grond van lid 1. Dit betekent dat de zorgverzekeraar ook een afwijking van een ongevraagd advies over het zorginkoopbeleid dient te motiveren, zo staat in de MvT. ${ }^{74}$ Het is inderdaad wenselijk om geen onderscheid te maken tussen een wettelijk verplicht advies en een nader overeengekomen adviesmogelijkheid.

\section{Toezicht en handhaving}

\subsection{Raad van commissarissen}

Ten opzichte van het Voorontwerp is de taak van de raad van commissarissen verduidelijkt. Van de raad van commissarissen wordt verwacht dat de raad erop toeziet dat de zorgverzekeraar in overeenstemming handelt met de voorgestelde bepalingen in dit Wetsvoorstel. De raad van commissarissen moet erop toezien dat de zorgverzekeraar de inspraakregeling niet eerder vaststelt dan nadat de vertegenwoordiging van verzekerden hiermee heeft ingestemd en dat de zorgverzekeraar deze inspraakregeling na vaststelling daadwerkelijk uitvoert, aldus de MvT. Het is nadrukkelijk niet de bedoeling dat de raad van com-

69 Zie hierover Klaassen, TvGR 2017, p. 16. Een overleg zorgt ervoor dat er naar elkaar (en de argumenten) wordt geluisterd. Hiermee wordt de gewenste dialoog bevorderd. De MvT (Kamerstukken II 2017/18, 34971, 3, p. 31) gaat in ieder geval bij een verschil van mening over de inspraakregeling (art. 28a lid 4 Zvw (nieuw)) wel uit van een overleg.

70 Kamerstukken II 2017/18, 34971, 3, p. 36.

71 Kamerstukken II 2017/18, 34971, 3, p. 36.

72 Zie Klaassen, TvGR 2017, p. 15. Zie art. 3 lid 3 Wmcz en art. 23 lid 3 WOR.

73 Zie par. 9, mijns inziens is een schriftelijke regeling voldoende.

74 Kamerstukken II 2017/18, 34971, 3, p. 36. 
missarissen de rol van klachten- of geschilleninstantie op zich neemt. ${ }^{75}$ Dit past ook niet bij de wettelijke taak van de raad van commissarissen. De raad van commissarissen kan wel een bemiddelde rol vervullen. Deze rol werd in de toelichting bij het Voorontwerp nog niet genoemd. ${ }^{76}$ Of de raad van commissarissen daadwerkelijk deze rol op zich wil nemen, is een andere vraag. Ik vermoed dat de raad wel op de hoogte wil zijn van 'conflicten' en eventueel op de partijen enige druk wil uitoefenen om tot een goede afloop te komen, maar dat de raad daarbij niet een soort scheidsrechterrol op zich wil nemen.

Tevens zal de raad van commissarissen er toezicht op moeten houden dat het instemmings- en adviesrecht wordt toegekend aan een permanente vertegenwoordiging die voldoet aan de wettelijke gestelde eisen en dat de vertegenwoordiging in de gelegenheid wordt gesteld haar adviesrecht ten aanzien van het jaarlijkse zorginkoopbeleid uit te oefenen. ${ }^{77}$

\subsection{Nederlandse Zorgautoriteit}

Ten opzichte van het Voorontwerp is de taak van de NZa duidelijker afgebakend. Dit is gebeurd naar aanleiding van opmerkingen van de Afdeling advisering van de Raad van State. ${ }^{78}$ Buiten het toezicht van de NZa vallen de met dit wetsvoorstel geïntroduceerde wettelijke verplichtingen die spelen in de relatie tussen de verzekerden/de vertegenwoordiging en de zorgverzekeraar. Onder het toezicht van de NZa vallen de vragen of (i) de statuten ${ }^{79}$ wel zijn ingericht conform het Wetsvoorstel, of (ii) er wel een permanente vertegenwoordiging functioneert, of (iii) die vertegenwoordiging zo veel mogelijk een (in de statuten uit te werken) goede afspiegeling van de verzekerden vormt en of (iv) de inspraakregeling en vacatures voor de vertegenwoordiging wel openbaar worden gemaakt, zo staat in de $\operatorname{MvT}^{80}$

\subsection{Kantonrechter}

Een grote wijziging ten opzichte van het Voorontwerp is dat artikel $115 \mathrm{Zvw}$ (nieuw) bepaalt dat zowel de permanente vertegenwoordiging als de zorgverzekeraar naar de kantonrechter kan stappen bij een verschil van inzicht. ${ }^{81}$ Het kan dan gaan om geschillen over de toepassing van de inspraakregeling, over de vraag of een zorgverzekeraar in een voorkomend geval terecht van mening is dat het onthouden van de instemming aan de inspraakregeling onredelijk is, over de vraag of de zorgverzekeraar adviezen van de vertegenwoordiging wel serieus neemt en over de vraag of de zorgverzekeraar wel voldoende in

Het is niet de bedoeling dat de raad van commissarissen de inspraakregeling toetst als de zorgverzekeraar er niet uitkomt met vertegenwoordiging en/of de vertegenwoordiging weigert in te stemmen.

76 Van de raad van commissarissen wordt verwacht dat, indien de zorgverzekeraar en de vertegenwoordiging er samen niet uitkomen, de raad van commissarissen de redelijkheid van de opstelling van het bestuur zal toetsen en zo nodig een bemiddelende rol zal spelen. Zie ook het advies van de Commissie Vennootschapsrecht, Bijlage bij Kamerstukken II 2017/18, 34971, 3.

78 Kamerstukken II 2017/18, 34971, 4, p. 4.

79 Zie par. 9, mijns inziens is een schriftelijke regeling voldoende.

80 Kamerstukken II 2017/18, 34971, 3, p. 25. Zie ook p. 32 en p. 33.

81 Zie hierover ook Kamerstukken II 2017/18, 34971, 4, p. 5. 
de kosten van de vertegenwoordiging voorziet, aldus de MvT.82 De toevoeging van dit nieuwe artikel is een enorme verbetering. ${ }^{83}$ Hiermee wordt de positie van de permanente vertegenwoordiging pas echt versterkt doordat het een en ander ter toetsing aan de rechter kan worden voorgelegd.

\section{Statuten}

Het Wetsvoorstel kent een (relatief) grote rol toe aan de statuten van een zorgverzekeraar. ${ }^{84}$ In tegenstelling tot het Voorontwerp ${ }^{85}$ komen in de tekst van het Wetsvoorstel de woorden 'statuten' of 'statutair' een aantal keer voor. Elke zorgverzekeraar wordt verplicht in zijn statuten een instemmingsrecht voor de inspraakregeling en een adviesrecht over het jaarlijkse zorginkoopbeleid aan de permanente vertegenwoordiging toe te kennen. ${ }^{86}$ Daarnaast wordt elke zorgverzekeraar verplicht de eisen aan de samenstelling van de permanente vertegenwoordiging in de statuten op te nemen. Ook dienen het aantal leden van de permanente vertegenwoordiging en de wijze van benoeming van de leden van de permanente vertegenwoordiging in de statuten te worden vastgelegd. ${ }^{87}$ De vraag is of de keuze voor vastlegging van deze gestelde eisen in de statuten wenselijk is. In mijn ogen is dat niet het geval.

\section{Samenloop Boek 2 BW}

De gemaakte keuze in het Wetsvoorstel voor statutaire eisen leidt tot onnodige complicatie vanwege de samenloop met Boek 2 BW. Vastlegging van bepaalde eisen in de statuten heeft tot gevolg dat, wanneer in strijd wordt gehandeld met deze statutaire eisen, de besluiten nietig zijn of vernietigd kunnen worden op grond van artikel 2:14 en 2:15 BW. ${ }^{88} \mathrm{Het}$ instemmingsrecht van de permanente vertegenwoordiging dient bijvoorbeeld in de statuten te worden opgenomen. Indien geen instemming aan de permanente vertegenwoordiging over de inspraakregeling wordt gevraagd door het bestuur van de zorgverzekeraar, wordt in strijd gehandeld met de statuten. Dit betekent dat het besluit van het bestuur van de zorgverzekeraar tot vaststelling van de inspraakregeling nietig is. Hetzelfde geldt als geen advies aan de permanente vertegenwoordiging wordt gevraagd. Weliswaar bevat artikel 28a lid 4 Zvw (nieuw) een 'oplossing' voor de situatie dat de permanente vertegenwoordiging weigert instemming te geven en zich hierbij onredelijk opstelt. Het bestuur van de

82 Gelet op het waarschijnlijk zeer geringe aantal gevallen waarin dergelijke geschillen aan de orde zullen zijn, is besloten om hiervoor geen geschilleninstantie in het leven te roepen; zie Kamerstukken II 2017/18, 34971, 3, p. 36.

83 Zie ook Klaassen, TvGR 2017, p. 18.

84 Om zorgverzekeraars voldoende tijd te geven om aan de wettelijke eisen te voldoen, zal tussen het moment van aanvaarding van deze wet door de Eerste Kamer en inwerkingtreding daarvan een periode van ongeveer zes maanden in acht worden genomen. Op deze manier wordt aan de zorgverzekeraars voldoende gelegenheid geboden hun statuten aan te passen. Zie Kamerstukken II 2017/18, 34971, 3, p. 38.

85 In de concept-MvT komen de woorden 'statuten' en 'statutair' wel voor.

86 Kamerstukken II 2017/18, 34971, 3, p. 31. Zie ook art. 28c lid 6 Zvw (nieuw). Hierin wordt expliciet bepaald dat de onderdelen waarover naast het jaarlijkse zorginkoopbeleid ook adviesrecht bestaat in de statuten dienen te worden opgenomen.

87 Art. 28b lid 2 en 3 Zvw (nieuw).

88 Art. 2:14 lid 1 of art. 2:15 lid 1 onderdeel a BW. 
zorgverzekeraar mag dan de inspraakregeling vaststellen. Dit is alleen een andere situatie dan wanneer het bestuur geen instemming van de permanente vertegenwoordiging vraagt, in dat geval kan de permanente vertegenwoordiging een beroep doen op artikel 2:14 lid 1 BW. Dit lijkt mij ongewenst.

De Commissie Vennootschapsrecht heeft op deze ongewenste samenloop al gewezen (in haar reactie op het Voorontwerp). ${ }^{89} \mathrm{Zij}$ wijst erop dat een statutaire regeling 'precaire vraagstukken van nietige en vernietigbare besluitvorming' met zich brengt. Als voorbeeld wordt genoemd dat wanneer leden in strijd met de statuten een vertegenwoordiging kiezen die geen goede afspiegeling vormt van de verzekerden (of dat die situatie ontstaat door het uittreden of toetreden van verzekerden), dit kan leiden tot een nietig besluit van deze permanente vertegenwoordiging. ${ }^{90}$ Uit de MvT blijkt dat deze situatie wordt voorkomen, doordat aan de eisen van samenstelling van de permanente vertegenwoordiging de woorden 'voor zover mogelijk' zijn toegevoegd. ${ }^{91}$ Ondanks deze aanpassing betekent dit dat wanneer geen instemming of geen (tijdig) advies wordt gevraagd (het eerste voorbeeld), dit nog steeds kan leiden tot nietige besluiten (in dit geval van het bestuur van de zorgverzekeraar). Op dit gevolg heeft de Commissie Vennootschapsrecht ook gewezen. In de MvT staat als reactie op het advies van de Commissie Vennootschapsrecht dat "niet wordt beoogd dat de vaststelling van de inspraakregeling of het zorginkoopbeleid, zonder instemming of advies van de vertegenwoordiging, nietig is' en verderop in de MvT staat dat 'nietigheid (...) een zware en ongewenste sanctie zou zijn, mede gezien de rechtsonzekerheid die de nietigheid met zich mee zou brengen'. ${ }^{92}$ Nietigheid treedt van rechtswege in en treft een besluit vanaf het begin. Elke belanghebbende kan hierop steeds een beroep doen. Deze sanctie raakt de besluitvorming (van het bestuur van de zorgverzekeraar) binnen een rechtspersoon. Rechtshandelingen die voortbouwen op deze besluiten kunnen ook ter discussie komen te staan. ${ }^{93}$

De samenloop met Boek 2 BW wordt voorkomen door in de Zvw niet de eis te stellen van statutaire vastlegging. Zonder statutaire vastlegging zijn de sancties in Boek 2 BW op grond van artikel 2:14 (en art. 2:15 BW) niet van toepassing. De Commissie Vennootschapsrecht heeft niet voor niets geadviseerd om de invloed van verzekerden niet te versterken 'via een wettelijke verwijzing naar een statutaire regeling'.

\section{Geschillenregeling in Zvw}

Daarbij komt dat de toepassing van artikel 2:14 (en art. 2:15 BW) uit Boek 2 BW niet nodig is. De handhaving van de nieuwe wettelijke regels is voldoende geregeld door de mogelijkheid naar de kantonrechter te stappen. ${ }^{94}$ Wanneer het bestuur van een zorgverzekeraar de inspraakregeling vaststelt (of wijzigt of intrekt) zonder dat hiervoor instemming van de permanente vertegenwoordiging is gevraagd, kan zij de kantonrechter verzoeken te bepalen dat de zorgverzekeraar gevolg dient te geven aan artikel 28a lid $4 \mathrm{Zvw}$ (nieuw). Ook voor schending van de bepalingen in de Wet op de Ondernemingsraden (WOR) en de 
Wmcz geldt een afzonderlijke rechtsgang, die bij die wetten is vastgelegd. In het geval van de WOR de Ondernemingskamer (OK) en de kantonrechter en in geval van de Wmcz de commissie van vertrouwenslieden en de kantonrechter. ${ }^{95}$ Naar mijn mening zorgt de voorgestelde geschillenregeling in de Zvw ervoor dat de weg van artikel 2:14 (en art. 2:15 BW) niet openstaat als gehandeld wordt in strijd met het instemmings- of het adviesrecht op grond van de Zvw. ${ }^{96}$ In de MvT staat dat het ongewenst is dat naast de mogelijkheid van de kantonrechter, een vennootschapsrechtelijke sanctie zou bestaan. ${ }^{97}$ Dit is eenvoudig te voorkomen door de eis van statutaire vastlegging te schrappen.

\section{Wettelijke eisen}

Bovendien is het niet nodig dat het instemmingsrecht en het adviesrecht in de statuten komen te staan, ${ }^{98}$ want deze rechten staan al in een wet. Uit de nieuwe bepalingen in de Zvw blijkt duidelijk dat de permanente vertegenwoordiging deze rechten op grond van de wet, namelijk de Zvw, heeft. ${ }^{99}$ Het opnemen van deze rechten in de statuten voegt aan het (wettelijke) recht zelf weinig toe. Dit geldt ook voor de eisen aan de samenstelling van de permanente vertegenwoordiging, zoals de 'afspiegelingseisen', het aantal leden en de wijze van benoeming. Het gaat om regels waaraan de zorgverzekeraar moet voldoen en waarvan de uitwerking in een schriftelijke regeling kan worden opgenomen. Indien de zorgverzekeraar hieraan niet voldoet, kan de NZa handhavend optreden. ${ }^{100}$ Waarschijnlijk zijn deze laatste statutaire eisen (aantal en wijze van benoeming) toegevoegd omdat Boek $2 \mathrm{BW}$ dit voor de ledenraad al bepaalt. ${ }^{101}$ Kennelijk is het de bedoeling dat deze eisen (ook) gelden voor de permanente vertegenwoordiging, ongeacht of de zorgverzekeraar kiest voor een ledenraad, een verzekerdenraad of een daartoe ingestelde vertegenwoordiging. In dit geval voegt de Zvw voor de ledenraad niets toe (zie Boek 2 BW) en voor de verzekerdenraad of een daartoe aangewezen vertegenwoordiging is een schriftelijke regeling voldoende. ${ }^{102} \mathrm{De}$ verzekerdenraad of een daartoe aangewezen vertegenwoordiging zijn en worden geen organen van de rechtspersoon, gezien de taken die de permanente vertegenwoordiging krijgt op grond van de nieuwe bepalingen in de Zvw. ${ }^{103} \mathrm{Zij}$ kunnen geen bindende besluiten voor de rechtspersoon nemen. Hun positie hoeft niet geregeld te worden in de statuten. Dit in tegenstelling tot de ledenraad, die wel een orgaan is van de rechtspersoon door de bevoegdheden die op grond van Boek 2 BW aan de ledenraad toekomen. Naar goed gebruik worden bijvoorbeeld bevoegdheden en het vereiste aantal leden van een orgaan

95 Art. 26, 27 en 36 WOR en art. $10 \mathrm{Wmcz}$.

96 Strijd met wettelijke bepalingen buiten Boek 2 BW kan ook tot nietigheid leiden, maar niet als een wet een eigen afgeronde sanctieregeling kent, zoals in het Wetsvoorstel. Zie Van Schilfgaarde/Winter \& Wezeman \& Schoonbrood, Van de BV en de NV, Deventer: Wolters Kluwer 2017, nr. 83 en 95. Zie ook Asser/Kroeze 2-1*, De rechtspersoon, Deventer: Kluwer 2015, nr. 612.

97 Kamerstukken II 2017/18, 34971, 3, p. 21.

98 Art. 28 lid 2 Zvw (nieuw) en Kamerstukken II 2017/18, 34971, 3, p. 10 en p. 31.

99 Art. 28a lid $4 \mathrm{Zvw}$ (nieuw) en art. 28c lid $1 \mathrm{Zvw}$ (nieuw).

100 Zie par. 8.2.

101 Art. 2:39 lid 1 BW.

102 Zie Klaassen, WPNR 2016/7130, p. 1033.

103 Voor de duidelijkheid, de ledenraad is (en blijft) wel een orgaan van de rechtspersoon. Zie voor de definitie P.J. Dortmond, Handboek Naamloze en besloten vennootschap, Kluwer: Deventer 2013, nr. 200. 
wel in de statuten opgenomen. Ik kom op de ledenraad als permanente vertegenwoordiging nog terug.

Ik spreek bewust niet van een reglement, maar van een schriftelijke regeling. Het gaat niet om een reglement in de zin van artikel 2:15 lid 1 onderdeel c BW. Het lijkt mij dat van een reglement in de zin van dit artikel alleen sprake is van een reglement van een orgaan van de rechtspersoon. ${ }^{104}$ Een verzekerdenraad en een daartoe aangewezen vertegenwoordiging zijn, zoals gezegd, niet bedoeld als organen van de rechtspersoon. Het in strijd handelen met een reglement van de ondernemingsraad of cliëntenraad leidt ook niet tot sancties op grond van Boek 2 BW. ${ }^{105}$

\section{Aanwijzen van een permanente vertegenwoordiging ${ }^{106}$}

Overigens kan worden afgevraagd of het wenselijk is dat het adviesrecht en instemmingsrecht op grond van de nieuwe Zvw aan de ledenraad moeten toekomen. De ledenraad krijgt dan naast zeggenschapstaken ${ }^{107}$ ook medezeggenschaptaken. Uit de MvT blijkt dat de permanente vertegenwoordiging wordt gecreëerd om vorm te geven aan de medezeggenschap van verzekerden. De invloed van de vertegenwoordiging gaat 'geenszins zo ver dat sprake is van een vetorecht', zo staat in de MvT. ${ }^{108}$ Met inspraak binnen deze wet wordt nadrukkelijk niet gedoeld op zeggenschap. ${ }^{109}$ Het gaat slechts om het uitoefenen van invloed op het beleid, maar niet om dat beleid te bepalen, aldus de MvT. ${ }^{110}$ Dit is vergelijkbaar met de medezeggenschap van de ondernemingsraad en de cliëntenraad. Het lijkt mij onwenselijk dat in een orgaan, zoals de ledenraad, zeggenschap en medezeggenschap door elkaar heenlopen. Er moet een duidelijk onderscheid zijn tussen de zeggenschap van verzekerden (als lid) op grond van Boek 2 BW en de medezeggenschap (als klant) op grond van de Zvw. De Commissie Vennootschapsrecht wijst er ook op dat de nieuwe regels in de Zvw op twee gedachten hinken. ${ }^{111}$

104 Een reglement is een samenstel van regels die het (interne) functioneren van de rechtspersoon en zijn organen betreffen. Zie Asser/Kroeze 2-1*, De rechtspersoon, Deventer: Kluwer 2015, nr. 184. Zie ook Dijk/Van der Ploeg, Van vereniging en stichting, coöperatie en onderlinge waarborgmaatschappij, Deventer: Kluwer 2013, p. 80.

105 Op grond van art. 36 WOR berust de toetsing van het OR-reglement bij de kantonrechter. Zie ook art. 8 WOR.

106 Art. 28 lid 2 Zvw (nieuw).

107 De ledenraad oefent, in plaats van de algemene (leden)vergadering, de bevoegdheden uit die op grond van Boek 2 BW aan de algemene vergadering toekomen (bijv. benoeming en ontslag van bestuurders en commissarissen, vaststelling jaarrekening). Hierdoor is de ledenraad een orgaan van de rechtspersoon omdat de raad voor de rechtspersoon bindende besluiten kan nemen.

108 Kamerstukken II 2017/18, 34971, 3, p. 11.

109 Kamerstukken II 2017/18, 34971, 3, p. 19.

110 Ook zullen de leden van de permanente vertegenwoordiging niet worden beschouwd als (mede)beleidsbepalers in de zin van de Wft. Dit was een zorgpunt van DNB. Zie hierover Kamerstukken II 2017/18, 34971, 3, p. 19.

111 De Commissie Vennootschapsrecht constateert (terecht) dat het conceptwetsvoorstel enerzijds beoogt aan te sluiten bij de bestaande rechtspersonenrechtelijke organen zoals geregeld in Boek 2 van het BW (door het stellen van statutaire eisen), terwijl anderzijds de wijze waarop de bevoegdheden zijn vormgegeven lijken te zijn geïnspireerd door de wettelijke bevoegdheden van ondernemingsraden en cliëntenraden. Het Wetsvoorstel blijft onterecht hinken op deze twee gedachten. 
Het aanwijzen van de ledenraad als permanente vertegenwoordiging gaat veel vragen oproepen. ${ }^{112}$ Dienen deze medezeggenschapsrechten op grond van de Zvw in de statuten te staan? Immers, naar goed gebruik worden bevoegdheden van een orgaan, zoals de ledenraad, in de statuten opgenomen. Zijn de sancties van Boek 2 BW wel of niet van toepassing als de ledenraad een besluit neemt? Moet per besluit worden bepaald of Boek 2 BW of de Zvw van toepassing is? Ik raad deze keuze voor zorgverzekeraars dan ook af, ook al sluit de ledenraad op het eerste gezicht het beste aan bij de praktijk. ${ }^{113}$

Waarom ligt een verzekerdenraad of een daartoe ingestelde vertegenwoordiging wel voor de hand? Een verzekerdenraad is net als de ledenraad een vertegenwoordiging van verzekerden, maar heeft niet dezelfde wettelijke (of statutaire) bevoegdheden als een ledenraad. ${ }^{114}$ Een verzekerdenraad heeft een klankbordfunctie in plaats van een zeggenschapsfunctie. Derhalve is de verzekerdenraad niet een orgaan van de rechtspersoon. De MvT verschaft geen duidelijkheid over wat een daartoe ingestelde vertegenwoordiging is. Het zal waarschijnlijk een soort 'raad' zijn, die vergelijkbaar is met een verzekerdenraad en om die reden geen orgaan is van de rechtspersoon, net zoals de ondernemingsraad en de cliëntenraad ook geen organen zijn van de rechtspersoon. ${ }^{115}$ Medezeggenschap kan goed door deze 'raden' worden uitgeoefend. ${ }^{116}$

Aanbeveling voor de wetgever

Mijn (dringende) aanbeveling is dan ook de woorden 'statuten' en 'statutair' in het Wetsvoorstel te schrappen. ${ }^{117}$ Voor de duidelijkheid, dit betekent niet dat in mijn ogen de gestelde eisen dienen te vervallen, alleen dat deze eisen niet in de statuten hoeven te worden vastgelegd, maar in een schriftelijke regeling. Een andere aanbeveling die hieruit voortvloeit, is onderdeel b van artikel 28 lid 1 Zvw te schrappen. Dit betekent ook dat artikel 28 lid 2 Zvw (nieuw) en de wijziging naar artikel 28 lid 2 in een aantal bepalingen dient te worden geschrapt.

De keuze om sommige eisen statutair vast te leggen vloeit waarschijnlijk voort uit artikel 28 lid 1 onderdeel $\mathrm{b}$ Zvw, waarin de verplichting staat dat in de statuten een redelijke mate van invloed van verzekerden moet worden geborgd. ${ }^{118}$ Bij de invoering van de Zvw was dit onderdeel al een vreemde eend in de bijt in vergelijking tot onderdeel a (een raad van com-

112 De vennootschapsrechtelijke en ondernemingsrechtelijke medezeggenschap van de ondernemingsraad roept al de nodige vragen op en in dit geval gaat het dan alleen om medezeggenschap. Zie I. Zaal, De reikwijdte van medezeggenschap, 2014, p. 13 e.v.

113 Zie Kamerstukken II 2017/18, 34971, 3, p. 5. Met de opmerking in de MvT (Kamerstukken II 2017/18, 34971, 3, p. 20-21) dat 'De eisen zijn dusdanig geformuleerd dat zij passend zijn voor alle zorgverzekeraars, ongeacht rechtsvorm of organisatiestructuur. Daarbij is gepoogd de wetsbepalingen zo te formuleren dat versterking van de positie van de verzekerde wordt bewerkstelligd, zonder dat bij afzonderlijke zorgverzekeraars organisatorische wijzigingen nodig zijn die in de praktijk onvoldoende toevoegen', ben ik het niet helemaal eens.

114 Kamerstukken II 2017/18, 34971, 3, p. 5.

115 Van Schilfgaarde/Winter \& Wezeman \& Schoonbrood 2017, nr. 74 (voor wat betreft de medezeggenschapsaspecten uit de WOR). Zie over dit punt ook, I. Zaal, De reikwijdte van medezeggenschap, 2014, p. 21.

116 Theoretisch moet het mogelijk zijn dat (een aantal) leden van de ledenraad ook lid qualitate qua zijn van een verzekerdenraad. Daarbij moeten dan wel de eisen van art. 28b Zvw (nieuw) in acht worden genomen.

117 Art. 28b lid 2 en lid 3 en art. 28c lid 6 Zvw (nieuw).

118 Kamerstukken II 2017/18, 34971, 3, p. 27/28. 
missarissen is verplicht) en onderdeel c (in het geval dat de zorgverzekeraar een onderlinge waarborgmaatschappij (OWM) is, dient de aansprakelijkheid van de leden uitgesloten te zijn, een zorgverzekeraar kan alleen een OWM U.A. zijn). Deze twee onderdelen, a en c, zijn wel Boek 2 BW relevante onderwerpen en dienen daarmee in de statuten te worden geregeld. Het is volgens mij onnodig krampachtig vast te houden dat op grond van onderdeel $\mathrm{b}$ de invloed van verzekerden in de statuten moet worden vastgelegd, om de eenvoudige reden dat die invloed nu in een wet, namelijk de Zvw, komt te staan. Statutaire bepalingen worden hierdoor overbodig en onderdeel b dus ook. Aangezien 'de redelijke mate van invloed' in het Wetsvoorstel (terecht) wordt benaderd vanuit de medezeggenschapsfunctie en daarmee dan ook niet thuis hoort in de statuten, kan dit onderdeel b in mijn ogen (dan ook) worden geschrapt.

\section{Conclusie en aanbevelingen}

De vraag van deze bijdrage was of het Wetsvoorstel een verbetering is ten opzichte van het Voorontwerp. Dat is inderdaad het geval, met uitzondering van één punt. De nadere invulling van een aantal gestelde eisen is een verbetering, evenals de wettelijke vastlegging van het ongevraagd adviesrecht en de aanvulling van de nieuwe regels met een geschillenregeling.

De eis dat bepaalde onderwerpen in de statuten van een zorgverzekeraar dienen te worden geregeld, is daarentegen zeer ongewenst. ${ }^{119} \mathrm{Op}$ dit punt is aanpassing van het Wetsvoorstel dringend gewenst. Mijn aanbeveling is dan ook artikel 28 lid 1 onderdeel b Zvw, artikel 28 lid 2 Zvw (nieuw), de verwijzingen naar dit lid 2, en de woorden 'statuten' en 'statutair' in artikel $28 \mathrm{~b}$ en artikel 28c Zvw (nieuw) te schrappen. 